\title{
A European Political System in the Making 1958-1970: The Relevance of Emerging Committee Structures
}

\author{
Ann-Christina L. KNUDSEN and Morten RASMUSSEN
}

Most observers of Europe today would without much hesitation characterise the European Union (EU) as a political system, in spite of the fact that it lacks features of classical statehood such as a single government, a coherent foreign policy and a standing army. ${ }^{1}$ The notion of a (European) political system is a descriptive category, not a teleological prediction of the development of the European integration process. Hence, it makes no statements about the possible obsoleteness of the member states, a question that was at the core of the original debate between neofunctionalists and intergovernmentalists in the 1960s. ${ }^{2}$ Even today, the member states continue to wield a dominant influence on the European political system. For example, the EU still relies primarily on the member states for implementing legislation and administering coercion. At the same time, the European political system constrains member state power and has in a number of ways been transforming the European nation-state. Some scholars even argue that the post-war European integration project constitutes a new phase in the development of the system of European states. ${ }^{3}$ The European Union institutions regularly interact with citizens and social groups. Supranational legislation affects everyday lives in Europe in a wide range of areas; from labour market rules to commodity standards to food safety, and also influences the distribution of economic resources throughout the Union. Crucially, the development of the European political system has gone hand in hand with the emergence of significant elements of transnational European society, in which national political and economic elites have participated at multiple levels, thus greatly extending the political, economic, social and legal space available to the citizens. ${ }^{4}$

It is typically suggested that the European political system came into being in earnest around the early or mid 1980s. ${ }^{5}$ This has been identified through developments such as the '1992-programme', the Single European Act (SEA), the

1. A seminal article: S. HIX, The Study of the European Community: The Challenge to Comparative Politics, in: West European Politics, (1)1994, pp.1-30 was the first to propose the use of comparative politics analytical tools to treat the EU as a domestic arena. A more comprehensive account was later provided in S. HIX, The Political System of the European Union, Macmillan, London, 1999.

2. E.B. HAAS, The Uniting of Europe. Political, Social and Economic Forces 1950-1957, Stevens \& Sons Limited, London, 1958; L.N. LINDBERG, The Political Dynamics of European Integration, Stanford University Press, Stanford, California, 1963; S. HOFFMAN, Obstinate or Obsolete? The Fate of the Nation-State and the Case of Western Europe, in: Daedalus, (4)1966, pp.862-915.

3. S. BARTOLINI, Restructuring Europe. Center Formation, System Building, and Political Structuring between the Nation-State and the European Union, Oxford University Press, New York, 2005. See also, S. ROKKAN, P. FLORA, S. KUHLNE, D.D. URWIN, State Formation, Nation-Building, and Mass Politics in Europe: the Theory of Stein Rokkan, Oxford University Press, New York, 1999. 
extension of the powers of the European Parliament (EP) as well as a further coding and extension of the so-called comitology committees. ${ }^{6}$ Moreover, there had been several enlargements, numerous instances of judicial activism by the European Court of Justice (ECJ), increasing activities among EP political party groups as well as a strong growth in the number of interest groups attracted to set up shop in Brussels. While these developments certainly contributed to strengthening the contours of the European political system, we find the starting date presented in this literature somewhat arbitrary. Instead, we argue that significant cornerstones of the emerging European political system were laid already in the early 1960 s. $^{7}$

Unfortunately, historiography of the European integration process has largely ignored the historical origins of the European political system. Rather, it tends to be steeped in a neo-realist state-centric paradigm, where the European policy appears merely as a foreign policy matter, and bargaining is conceived in terms of rigid two-level games. This, we contend, is a major reason why the historiography of European integration is somewhat isolated from mainstream historical research in post-war European history ${ }^{8}$ and used mainly by other scholars as a useful collection of dates, facts, and figures about the past, rather than as a stepping stone to conceptualise or theorise fundamental questions about the nature of political, economic and social structures of contemporary Europe. ${ }^{9}$ In this article, we therefore wish to address how a connection can be established between the traditional state-centric approach to European integration history and the conceptualisation of the European Communities (EC) as it developed as an emerging European political system in the 1960s.

The empirical case study presented in this article is an examination of an area of fundamental importance to identifying the emerging European political system, namely the establishment of various committee structures that furthered what some

4. Consult W. KAISER, B. LEUCHT in this volume for the argument that transnational networks were important in the early phases of European integration history; for a general treatment, see W. KAISER, P. STARIE (eds.), Transnational European Union. Towards a Common Political Space, Routledge, London, 2005.

5. E.g. L. HOOGHE and G. MARKS, Multi-Level Governance and European Integration, Rowman and Littlefield Publishers, Lanham MD., 2001; W. SANDHOLTZ, J. ZYSMAN, 1992: Recasting the European Bargain, in: World Politics, (42)1992, pp.95-128.

6. E.g. T. CHRISTIANSEN, E.J. KIRCHNER (eds.), Committee Governance in the European Union, Manchester University Press, Manchester, 2000.

7. This argument is also launched much more comprehensively in W. KAISER, B. LEUCHT, M. RASMUSSEN (eds.), The History of the European Union. Origins of a Trans- and Supranational polity, Routledge, London, 2008, (forthcoming).

8. The same is the case with prominent sociologists of the longer-term post-war developments such as Colin Crouch and Gøsta Esping-Andersen, who have practically ignored European integration history.

9. Examples of this trend: B. RITTBERGER, Building Europe's Parliament. Democratic Representation beyond the Nation-State, Oxford University Press, Oxford, 2004; C. PARSON, A Certain Idea of Europe, Cornel University Press, Ithaca/London, 2003; E. MAHANT, Birthmarks of Europe. The Origins of the European Community Reconsidered, Ashgate, Bulington, 2004. 
scholars have termed the politico-administrative "fusion" between national and European administrative levels. ${ }^{10}$ We have examined the Committee of Permanent Representatives (COREPER) and the Special Committee for Agriculture (SCA), which is placed under the Council of ministers, as well as the management and advisory committees under the Commission - later codified as comitology committees - in the field of agriculture. Only the COREPER was vaguely mentioned in the founding treaties, yet all were established during the very early years of the Communities, namely between 1958 and 1962. Subsequently, they obtained a crucial role in the preparation, passing, and implementation of EC legislation. We examine the decisions to establish these committees, their functions, and the consequences they had over time. Quite a rigid line is often drawn between the preparatory committees of the Council and those involved in advising and implementation under the Commission. However, we have chosen to conceive of these committees as all being involved in the same political process. Crucially, the historical literature has only marginally dealt with the origins, role and consequences of these committees, and the emerging literature focuses above all on the role of the COREPER.${ }^{11}$ While the tendencies traced in this article are based extensively, although by no means exclusively, on the experiences of agriculture, thus reflecting the facts that this field saw the development of a European policy early on and caused the majority of European legislation in the 1960s, we claim that they eventually would apply across the policy fields of EC.

This article is structured as follows: Firstly, we discuss how the historiography of European integration has been circling around the conceptualisation of the emerging European political system rather than addressing it directly. Secondly, we discuss how social science theories can be made relevant to this type of historical research. We give the example of how recent institutionalist theories provide a useful starting point, but also discuss why they should not be taken as stringent predictors of the outcome of a historical analysis. We present our empirical study along with a discussion of the limitations of the notion of member state control when confronted with the virtual explosion of committees that took place already in the early 1960s. Following the case studies, we point to new areas where historical research may provide highly relevant inputs to the interdisciplinary debate on the emergence of the European political system. This, we argue, lies as a logical extension of the larger historical questions outlined above.

10. W. WESSELS, An Ever Closer Fusion? A Dynamic Macropolitical View on Integration Processes, in: Journal of Common Market Studies, (35)1997, pp.267-299.

11. N.P. LUDLOW, Mieux que six ambassadeurs. L'émergence du COREPER durant les premières années de la CEE, in: L. BADEL, S. JEANNESSON, N.P. LUDLOW (eds.), Les administrations nationales et la construction européenne. Une approche historique (1919-1975), P.I.E. Peter Lang, Brussels, 2005, pp.337-356; N.P. LUDLOW, A Controlled Experiment: The European Commission and the Rise of COREPER, in: W. KAISER, B. LEUCHT, M. RASMUSSEN (eds.), The History of the European Union ..., op.cit. 


\section{A historiography buried under facts and figures?}

The historiography of the post-war European integration process is largely confined to periods where archives are open, though new inroads are being made with newer methods such as oral history. ${ }^{12}$ The historiography is still overwhelmingly state-centric, and to some extent caught in the double bind that characterised the professional discipline of history as it emerged in the second half of the nineteenth century to legitimise the establishment of the various European nation-states. ${ }^{13}$ Thus, as they have been 'snow-ploughing' their way through state archives, historians have portrayed European integration as an endless series of inter-state negotiations, treaties, economic preferences and national interests. ${ }^{14}$ From this perspective European integration history is largely conceived of as a two-level game with very little attention given to formal and informal political structures that may cut across or go beyond these two-level games. Even the more conceptually sophisticated and innovative contributions seem to circle around the issue of a political system beyond the nation-state rather than addressing it directly.

The pioneering work of Alan S. Milward certainly helped to contextualise governments, diplomats and political elites within broader socio-economic and political interests. Yet, he maintained the focus on the nation-state, explaining the foundation of the EC in 1958 as the 'European rescue of the nation-state'. ${ }^{15}$ The quest for a true supranational history has been advanced most forcefully by $\mathrm{N}$. Piers Ludlow's rich political history of the EC from 1963 to $1969 .^{16}$ While this work successfully avoids placing nation-states alone at the centre of the EC, the analysis still leaves supranational actors such as the ECJ, the EP, as well as changing administrative and political organisational patterns, relatively unexplored. The late 1990s and early 2000s have witnessed several new contributions dealing

12. Oral history has been used extensively as an important supplement to archival sources in the new comprehensive history of the European Commission from 1958 to 1972: M. DUMOULIN, The European Commission, 1958-1972, History and Memories, Office des publications officielles de l'UE, Luxembourg, 2007.

13. G. IGGERS, Historiography in the Twentieth Century. From Scientific Objectivity to the Postmodern Challenge, Wesleyan University Press, Hanover/London, 1997.

14. The snow-plough metaphor used by N.P. Ludlow at the conference, 'L'expérience européenne: 50 ans de construction de l'Europe 1957-2007 in Rome, 22-24 March 2007 referring above all to the series of the Groupe de Liaison beginning with R. POIDEVIN (ed.), Histoire des débuts de la construction européenne (mars 1948-mai 1950), Bruylant, Brussels, 1986. The most recent volume is J. VAN DER HARST (ed.), Beyond the Customs Union: The European Community's Quest for Deepening, Widening and Completion, 1969-1975, Bruylant, Bruxelles, 2007. The only exception to this general rule is A. VARSORI (ed.), Inside the European Community. Actors and Policies in the European Integration 1957-1972, Nomos, Baden-Baden, 2006 that deals explicitly with transnational networks and European institutions.

15. A.S. MILWARD, The Reconstruction of Western Europe 1945-1961, Methuen, London, 1984; Idem., The European Rescue of the Nation-State, Routledge, London, 1992; Idem. et al., The Frontier of National Sovereignty. History and theory 1945-1992, Routledge, London, 1993.

16. N.P. LUDLOW, The European Community and the Crises of the 1960s: Negotiating the Gaullist Challenge, Routledge, London, 2006. 
with various European institutions. ${ }^{17}$ Many of these contributions have offered valuable empirical studies of for example the European Commission and the Economic and Social Committee. ${ }^{18}$ However, this new literature remains conceptually and theoretically rudimentary and crucially does not systematically contextualise the European institutions in the broader framework of an emerging European political system. ${ }^{19}$ With Orchestrating Europe, Keith Middlemass attempted to do exactly that, but in his otherwise major contribution, he maintained the fundamental logic of member state control, leaving no independent causal effects for institutional dynamics. ${ }^{20}$

As a result, from the point of view of the historical origins of the European political system, current historiography still contributes very little. Crucially, it remains conceptually underdeveloped with regard to the highly pertinent larger question of how the nature of the nation-states as social organisations adapted and changed in this period, with respect to developments at the European level. It is thus symptomatic that most of the literature still entertains an uncritical approach to notions of sovereignty and member state control over the European integration process. ${ }^{21}$ We do not propose the abandonment of the study of national history and policy-making as a central dimension of historiography of European integration. Understanding the domestic socio-economic and political dynamics that shape national European policies are fundamental to any analysis of EU history, but national histories do not add up to the history of the emerging European political system. It is thus high time that historians begin to write the early history of the present day European political system, using conceptualisations that are widely available and used for studies of modern political systems. Such a shift in the research agenda of European integration historiography is all the more relevant if historical research wishes to open up and thus further the interdisciplinary dialogue with social scientists, which in turn is necessary if historians of European integration want to abandon the relative intellectual isolation within which they find themselves.

17. Antonio Varsori has been the leading promoter of this research agenda. See A. VARSORI, Lo storiografia sull'integrazione europea, in: Europa Europe, (1)2001, pp.60-93.

18. See respectively M. DUMOULIN, The European Commission ..., op.cit., and A.VARSORI (ed.), Il Comitato Economico e Sociale nella costruzione europea, Marsilio, Venezia, 2000. See also the various contributions in A. VARSORI (ed.), Inside the European Community ..., op.cit., and W. LOTH (ed.), La gouvernance supranationale dans la construction européenne, Bruylant, Bruxelles, 2005.

19. This is most evidently the case with W. LOTH (ed.), La gouvernance supranationale ..., op.cit., while in particular A.VARSORI (ed.), Il Comitato Economico e Sociale ..., op.cit., goes relatively far in exploring among other issues the relationships between the Economic and Social Committee and other European institutions.

20. K. MIDDLEMAS, Orchestrating Europe. The Informal Politics of European Union 1973-1995, FontanaPress, London, 1995, pp.686-698.

21. A useful and systematic contribution to the discussion of post-war sovereignty: L.H. RASMUSSEN, De Overstatslige Dannelsers Tid. En Makrohistorisk Undersøgelse af Dansk Suveranitet og Internationalt Samarbejde 1945-2002 med sarligt Henblik på EF/ EU-Medlemsskabet, Dissertation, Aarhus University, Århus, 2008. 


\section{Bringing in a conceptual point of departure}

Social science theories and conceptualisations of institutional change provide a good starting point for interpreting the kind of empirical data generated through research in political archives. In particular, this body of literature offers much more refined theories and conceptualisations of the relationship between the member states and the European institutions than current historiography. We do not recommend a wholesale adoption of social science methodology, however. Social science conceptualisations and theories should function as the starting point for historical research to systematise and filter the maze of information of the empirical world. Hence, theories should not be used as check-lists in empirical historical research, but should be seen for what they are, namely simplified models of the world. We contend that ultimately, carefully researched historical narratives can provide unique new insights that will challenge theoretical models, as they adopt multicausal explanations of historical processes, rephrase classical ontological dichotomies (such as agent versus structure or ideational versus material factors) as empirical questions to which concrete answers can be given and offer empirically grounded indications of the limits to meaningful generalisation. $^{22}$

If we wish to explain the emergence of committees in international organisations - the example given in this article - a suitable theoretical in-road could be recent institutionalist theories from the social sciences. Arguably, the most prominent approach is the so-called principal-agent model from the rational institutionalist school, which has been conceptually refined within studies of the American congress. The principal-agent model has been widely used for the study of international organisations, and thus also the European Union. ${ }^{23}$ The basic assumptions are that principals (the member states) delegate authority to agents (the European institutions) in order to lower the costs associated with international cooperation, to increase the efficiency of cooperation, and to make their commitment credible. The theory assumes that all political actors act within a certain bounded rationality. Accordingly, ideas, ideologies and personalities, for example, are considered as only secondary. The theory assumes that agents such as committees or the Commission will systematically try to widen their own competences, and thereby try to make their own imprint on policy outcomes. ${ }^{24}$

22. For a precise and poignant defence of the historical narrative consult: J.L. GADDIS, The Landscape of History. How Historians Map the Past, Oxford University Press, Oxford, 2002. The relationship between history and the social sciences is discussed in the provocative: J.L. GADDIS, History, Science, and the Study of International Relations, in: N. WOODS (ed.), Explaining International Relations since 1945, Oxford University Press, Oxford, 1996, pp.32-48.

23. A. MORAVCSIK, The Choice for Europe. Social Purposes \& State Power from Messina to Maastricht, Cornell University Press, Ithaca/New York, 1998; M.A. POLLACK, The Engines of European Integration - Delegation, Agency, and Agenda Setting in the EU, Oxford University Press, New York, 2003; G. MAJONE, Dilemmas of European Integration - The Ambiguities and Pitfalls of Integration by Stealth, Oxford University Press, New York, 2005.

24. M.A. POLLACK, The Engines of European Integration ..., op.cit., pp.19-56. 
Therefore governments in response set up administrative procedures to define the scope of activities of agents and oversight procedures to be able to sanction errant agents. In the context of the EU, the COREPER, the SCA and comitology are examples of such administrative and oversight procedures, rational institutionalist scholars have argued, because they in different ways enable the member states to control and steer Commission behaviour.

The principal-agency model, in short, provides a useful and simple model for thinking about the hierarchies established within the EC/EU. It does not, however, claim to be an accurate description of them. ${ }^{25}$ That is rather an empirical question, and the answer should not be limited by the claims of this theory alone. Delegation-agency theory, however, works with a relatively static view of time. A second institutionalist school, historical institutionalism has argued that the introduction of the temporal dimension into the principal-agent theory clearly demonstrates that member states cannot control the consequences of delegation. The establishment and gradual development of European institutions and policies create path dependent processes and unintended consequences that over time slowly reshape the context within which European politics play out. Hence, governments cannot easily control or correct the processes set in motion because they would incur high costs. ${ }^{26} \mathrm{~A}$ final strand of institutionalist literature to be brought out here is that inspired by sociological theory. This is shown for instance in the work of social scientists Christian Joerges and Jürgen Neyer who, on the basis of studies of EU foodstuff regulation, have shown that the nature of the negotiations in the Council and Commission committees is often deliberative. They explain this with the overlapping membership of national experts, where long-term socialisation in European level committees undermines the notion of strict member state control. ${ }^{27}$

\section{Beyond member state control? Tracing an administrative mutation}

From 1958 to 1962, the EC witnessed a political and administrative mutation that reconfigured the policy process in comparison to the formal set-up in the founding treaties. Article 151 in the treaty of the European Economic Community (EEC) did

25. M.A. POLLACK, The New Institutionalisms and European Integration, in: A. WIENER, T. DIEZ (eds.), European Integration Theory, Oxford University Press, Oxford, 2004, pp.137-158, here pp.142-146.

26. P. PIERSON, The Path to European Integration: A Historical Institutional Analysis, in: Comparative Political Studies, (2)1996, pp.123-163; P. PIERSON, Politics in Time. History, Institutions, and Social Analysis, Princeton University Press, Princeton/Oxford, 2004.

27. C. JOERGES, J. NEYER, Transforming Strategic Interaction into Deliberative Political Process: European Comitology in the Foodstuffs Sector, in: Journal of European Public Policy, (4)1997, pp.609-625; C. JOERGES, J. NEYER, From Intergovernmental Bargaining to Deliberative Political Process: The Constitutionalization of Comitology, in: European Law Journal, (3)1997, pp.273-299. 
offer the Council the option to set up a committee of national representatives as part of the internal procedural rules. ${ }^{28}$ However, few observers were able to predict the size of the new committee structure that would eventually emerge under the formal leadership of the Council and work in parallel with the so-called expert groups of the Commission, which experienced a similar dramatic increase in numbers. Likewise, no one really anticipated the extent to which experts and officials from national ministries would participate in this new dual committee structure. Leon Lindberg, an early scholar of European integration, calculated that already by 1960 there were 127 expert groups under the Commission and more than 30 working groups under the COREPER. Lindberg's qualified guess was that as many as 17,540 national officials participated annually in the new committee structure, though there was probably a large degree of duplication in terms of the people involved. ${ }^{29}$ We will now examine the participation of national experts and officials more closely.

The COREPER was established on 24 January 1958 with the purpose of organising the work of the Council of general affairs, in particular to set up and lead the various working groups that would prepare European legislation. ${ }^{30}$ However, already in May 1960, the Council of general affairs decided to delegate the preparatory work further and created the SCA that would function in the area of agriculture, but in parallel with the COREPER. The SCA was expected to prepare the ground for the forthcoming negotiations on the CAP and to report almost exclusively to the Council of Agriculture ministers, which was the first new constellation of the Council. ${ }^{31}$ Considering that around $90 \%$ of all Community legislation between 1958 and 1965 was related to the CAP, the importance of the SCA functioning in parallel to the COREPER can hardly be underestimated. Other parallel committees were also established under the Council during the first half of the 1960s. Among these was the Special committee for Article 111, which supervised the Commission in commercial negotiations ${ }^{32}$, as well as various committees dealing with macro-economic and monetary policies. These committees would not all report to the Council of general affairs; for example, the various committees on economic and monetary policies would report to the newly

28. Already in 1953 the ECSC Council established a Coordinating Committee (COCOR) with task similar to the COREPER. Important differences were that the COCOR did not meet regularly and that members were not permanently based in Luxembourg.

29. L.N. LINDBERG, The Political Dynamics ..., op.cit., pp.55-58.

30. P.-H.J.M. HOUBEN, Les conseil des communautés européennes, A.W. Sythoff, Leyde, 1964, p.141; M. DUMOULIN, The European Commission ..., op.cit., p.46.

31. For the legal circumstances, see F. HAYES-RENSHAW, H. WALLACE, The Council of Ministers, Palgrave Macmillan, Basingstoke, 2006, $2^{\text {nd }}$ ed., p.94. For the political circumstances, see A.-C.L. KNUDSEN, Defining the Policies of the Common Agricultural Policy. A Historical Study, Dissertation, European University Institute, Florence, 2001, pp.215 ff.

32. L. COPPOLARO, Trade and Politics Across the Atlantic. The European Economic Community (EEC) and the United States of America in the GATT Negotiations of the Kennedy Round (1962-1967), Dissertation, European University Institute, Florence, 2006, pp.123-125. 
formed Council of Finance ministers. ${ }^{33}$ On top of this, each committee would set up ad hoc working groups to deal with specific issues. ${ }^{34}$

A similar development took place in the Commission, where a large number of expert groups were established in various policy fields, composed of Commission officials and their colleagues from the national administrations, as well as members recruited from major social partners in the field. This committee structure became particularly pronounced in the area of agriculture. Hence, with the first major CAP regulations in January 1962 came the formation of the management and advisory committees under the Commission, which were involved in the monitoring and implementation of Community legislation related to the CAP. The management committees involved representatives from the Commission and high-level officials from the national Agriculture ministries, and the advisory committees drew in the main social partners in the area of agriculture, who until then had only been marginally included in the policy process through the Economic and Social Committee.

The standard explanation by principal-agency theory of the emergence of the new committee structure under the Council, and of the establishment of the management and advisory committees in the field of implementation, is that they represented an attempt by the member states to shape, oversee and control the activities of the Commission. New historical research by N. Piers Ludlow on the COREPER has shown that this committee held multiple functions that went beyond merely controlling the Commission. In spite of this observation Ludlow concludes that although the COREPER's functions went beyond the narrow claims of principal-agent theory, the emergence of the new committee structures constituted a successful attempt by the member states to control and steer the EC as it developed during the 1960s. With important public policies such as the CAP at stake at the European level, it may be argued that this was a logical and rational step by the member states in their quest to control the European executive. Moreover, it could be argued that the establishment of the committees with national representatives under the Council constituted an attempt to establish the governments' own source of information regarding developments in European politics and policies, as they may have been seen as a more independent source of technical expertise compared to that provided by the Commission. ${ }^{35}$ Recent historical research on the EEC of the 1960s has also found numerous examples of how the member state governments with varying degree of success attempted to use the committees to censure and control the Commission. ${ }^{36}$ Apparently, these

33. É. NOEL, H. ÉTIENNE, The Permanent Representatives Committee and the 'Deepening of the Communities, in: G. IONESCU (ed.), The New Politics of European Integration, MacMillan, London, 1973, pp.98-123.

34. L.N. LINDBERG, The Political Dynamics ..., op.cit., pp.59-60.

35. N.P. LUDLOW, Mieux que six ambassadeurs ..., op.cit., pp.351-354; N.P. LUDLOW, A Controlled Experiment ..., op.cit.

36. Idem. for some striking examples of member state censoring of the Commission. 
examples confirm the intergovernmentalist story line ultimately promoted in the conclusions by supranationalist historians such as Ludlow.

We agree that it is certainly plausible that an implicit or explicit wish for control drove member state governments to establish the various committee structures. At the same time, however, we find the overall interpretation along intergovernmentalist lines deeply problematic. As has been pointed out in other scholarship on delegation-agency models, an implicit normativity is easily developed, namely the expectation that governments should want to or should be able to control their agents. ${ }^{37}$ Instead, we will outline below how the new committee structures in the Council and Commission over time actually created a functional division of tasks in Community affairs that fundamentally blurred some of the different political levels in the policy process. Committees came to function as a very broad and diverse interface between the European administration and the national administrations. This fundamentally changed the nature of European politics from foreign affairs to domestic affairs and created a 'fusion' - as identified by Wolfgang Wessels - between the national and European levels of administration and policy-making. This, we argue, was not expressedly a result of member states wanting to 'control' the European integration process. While the 'domestication' of European affairs has been pointed out before, hardly any historical analyses have so far tried to identify how, when or why these crucial changes occurred. We argue that the sum of new committee structures was crucial in the structural changes or mutations of interstate relations in the EEC in the 1960s. While this reduced the extent to which member states could function as unitary actors and essentially lessened their 'control' over the ongoing integration process, it also resulted in a somewhat less confrontational and more deliberative nature of communication between these states than the eternal focus on bargaining, projected by intergovernmentalist models of European integration history, would lead us to believe.

A functional division of labour immediately became present with the establishment of specialised compositions of the Council. The first to emerge was the Council of Agriculture ministers, which began as an informal framework, but became more prominent when it began to discuss the Commission's grand proposal for the CAP around the summer of 1960. This specialisation became even more institutionalised with the creation of the SCA in May 1960, which came to function as a preparatory committee for Council of agriculture meetings, and thus became the agricultural counterpart to the COREPER. Rather than framing them in terms of direct member state control, these functional divisions within the Council could also be seen as the consent by the member state governments of the fact that Community policy-making was so demanding and complex that it was impossible for them to act with a single voice, even towards their own highest decision-making setting. As the internal coordination of government policy positions towards the

37. R.B. ANDEWEG, On Studying Governments, in: J. HAYWARD, A. MENON (eds.), Governing Europe, Oxford University Press, Oxford, 2003, pp.39-60, here pp.52-53. 
Community varied strongly, there were important differences between the extent to which governments were able to perform total control over the presentation of 'national' positions. ${ }^{38}$

The functional division of tasks was accompanied by a blurring of the de facto and de jure decision-making in the Council. In January 1962 a new procedure for Council agendas was introduced, aiming at making matters run more smoothly in light of the rapid increase in the volume of Community legislation. ${ }^{39}$ Council agendas subsequently became divided into A- and B-items. 'B-items' were issues considered so politically important that only the ministers could close the dossier. 'A-items', however, could automatically be adopted by the two main preparatory committees of the Council, i.e. the COREPER and the SCA. This division of labour was drawn from French administrative practice, where politically minor and 'technical' issues could be treated and practically finalised at the level of politically nominated officials. ${ }^{40}$ Legally speaking, the COREPER and the SCA could not close A-item cases, but if agreement were reached in substance, the Council would typically simply pass A-items on the agenda automatically. Thus, the COREPER and the SCA became de facto legislators on A-item decisions, apart from the relatively few cases where the Commission demanded that a question should be examined by the Council. ${ }^{41}$

The so-called 'A-item procedure' became from then on perhaps the most significant function of the COREPER and the SCA in their preparation of the Council's work. Already in 1964, during its second year, this procedure constituted 138 out of 192 Council decisions. ${ }^{42}$ Studies of decision-making in the Council of agriculture during later periods have indicated that around $65 \%$ of Council agenda items were in fact listed as A-items, which the ministers consequently did not discuss in their meetings. Moreover, the same studies showed that only $13 \%$ of the $\mathrm{B}$-items on the Council agenda required decisions of a legally binding nature by the ministers. ${ }^{43}$ While there most likely were significant fluctuations of how this work was organised between A- and B-items, depending on the country of presidency, this still indicates the significance of the practice that had developed since the early 1960s of moving the bulk of decision-making one step down the hierarchy, from ministers to high-level officials and permanent representatives in the COREPER as well as the SCA.

38. In A.-C.L. KNUDSEN, Creating the Common Agricultural Policy. Story of Cereal Prices, in: W. LOTH, (ed.), Crises and Compromises: The European Project 1963-1969, Nomos Verlag, Baden-Baden, 2001, pp.131-156, this is exemplified with regard to Germany in the field of agricultural policies.

39. É. NOEL, H. ÉTIENNE, The Permanent Representatives ..., op.cit., pp.108-109.

40. N.P. LUDLOW, Mieux que six ambassadeurs ..., op.cit., p.339.

41. For the case of the SCA, see M.P.C.M. van SCHENDELEN, 'The Council Decides': Does the Council Decide?, in: Journal of Common Market Studies, (4)1996, pp.331-348.

42. N.P. LUDLOW, Mieux que six ambassadeurs ..., op.cit., p.339.

43. M.P.C.M. van SCHENDELEN, 'The Council Decides' ..., op.cit., p.540. 
It is often argued that the practice of A- and B-items did not represent a loss in political control over Community decision-making on the part of the governments. The large majority of A-items were, according to this view, purely technical questions that had to be removed from the Council table for the politicians to be able to address more pertinent political questions. Moreover, this practice is claimed to be comparable to the development of similar administrative routines in Western European democratic states in the post-war period. ${ }^{44}$ This view, we would suggest, underestimates the true nature of the decision-making process that developed. To begin with, the Council of ministers cannot be compared to a government with a cabinet, and there was no single principal in the Council that controlled the preparation of legislation, negotiated the final draft legislation and overviewed implementation in the Community. Instead, these tasks were partly delegated to the Commission, partly maintained within the competences of the Council. The establishment of the committee structures of the EC and the functional division of labour, combined with the establishment of the new decision-making procedures, meant that it in fact became extremely difficult even for the Commission or the COREPER to maintain an overview of the full range of activities of the Communities.

The picture is further complicated by the fact that the preparatory committees under the Council soon began to create a long series of sub-committees and working groups. In a fairly short space of time, the COREPER and the SCA each established around thirty technical working groups that covered most aspects of Community activities. In addition, each common market organisation of the CAP was equipped with both a management and an advisory committee, so that by the end of the decade there were around two dozen of each type of these committees. Both the Council and the Commission committee structures drew their membership from a mixture of Commission officials, officials from the national permanent representations and a wide spectrum of high- and middle-ranking national officials and experts. Commission officials took part in Council committee meetings, and representatives from national administrations largely populated the committee structures under the Commission. Most of these people came from levels below political officials or permanent representatives. ${ }^{45}$ Exact studies of the workings of these committees during the first decades do not yet exist, and therefore we do not know exactly what this meant in terms of member state control or bargaining. However, estimates exist for later periods, suggesting that nearly eighty percent of all differences in the positions of national governments were resolved already at the level of the working groups beneath the Council's preparatory committees, and that as much as ninety percent of the final Council texts were already produced in substance at this sub-committee level ${ }^{46}$ This meant that the number of cases that

44. N.P. LUDLOW, Mieux que six ambassadeurs ..., op.cit., p.339. See also for a much more critical view: D. DINAN, Ever Closer Union. An Introduction to European Integration, Palgrave, London, 2005, p.251.

45. P.-H.J.M. HOUBEN, Les conseil des communautés européennes ..., op.cit., p.149.

46. M.P.C.M. van SCHENDELEN, 'The Council Decides' ..., op.cit., p.535. 
had to be negotiated in the Council was significantly reduced. It also means that there is good reason to question whether the mythical statement that "the Council decides" was in fact an adequate way of describing decision-making in the EC.

In addition to this, the Commission's management committees that were engaged with the implementation of the CAP's agricultural market and price regimes took a large workload off the Council and the SCA, as practically all such technical issues had actually been discussed and often modified in talks involving the Commission and the relevant national administrations. Thus, by the end of the 1970s, it was observed that these committees served to "relieve the Council of involvement in the myriad details of the approximately 2000 regulations issued each year by the Community in order to administer the CAP" ${ }^{47}$ Considering just how many committees had become involved in the ongoing process of deliberation and the pervasiveness of consensus culture, it was becoming ever more difficult to point to exactly who had ownership over Community legislation.

The consequence of the emerging committee structures was that an increasing stream of national officials from various administrative branches began to travel frequently to meetings in the various committee structures under the Council and the Commission. With them, information and communication became highly dispersed, and the number of contact points between the national and European administrations increased considerably. Most notably is perhaps the estimate by the then secretary-general of the Commission, Émile Noël, that the Commission alone by the mid 1960s was in a position to draw on the expertise of as many as 14-15,000 national experts. ${ }^{48}$ This figure suggests a further increase in numbers from 1960 to the middle of the decade, compared with the number cited above by Lindberg that covered both Commission and Council committee structures.

The Council made several attempts to control these flows. Already in 1961, for instance, it was decided that the steady stream of information produced by the Commission should be channelled to the national administrations through the COREPER.$^{49}$ By the mid-1960s, certain member governments began to demand that the Commission's invitations of national officials should go through the COREPER and tightened the control of expenditures related to these invitations. This was re-confirmed in relation to the Luxembourg compromise in 1966, so that pre-consultations between the Commission and the member states would now have to be organised by the COREPER.$^{50}$ This did not, however, actually prevent contact of a more informal nature from evolving between the Commission and national officials and experts as the multiple layers of committee structures under the Commission as well as under the COREPER and the SCA continued to expand.

47. W.J. FELD, Implementation of the European Communities' Common Agricultural Policy: Expectations, Fears, Failures, in: International Organization, 3(1979), pp.335-363, here p.346.

48. N.P. LUDLOW, A Controlled Experiment ..., op.cit.

49. J. SALMON, Les représentants et missions permanents auprès de la CEE et de l'Euratom, in: M. VIRALLY, P. GERBET, J. SALMON, (eds.), Les missions permanentes auprès des organisations internationales, Bruylant, Bruxelles, 1971, p.634.

50. N.P. LUDLOW, Mieux que six ambassadeurs ..., op.cit., pp.344-346. 
Indeed, already during the first decade observers pointed out that for the area of agriculture alone "dozens, if not hundreds, of civil servants regularly commute from their national capitals to Brussels to serve this committee structure". ${ }^{51}$ Prior to the 2004 enlargement, it was estimated that more than a thousand people travelled to Brussels on a daily basis for similar purposes. ${ }^{52}$

The consequences of these committees over time were multiple. Firstly, a politico-administrative "fusion" took place between the member state and European administrative systems. ${ }^{53}$ This soon became evident in the field of agriculture that we have mainly surveyed here, but it was a development that spread to all other areas that the EC was involved in. Thus, at the level of officials, an increasing institutional and personal overlap occurred between the national agriculture ministries, the SCA, and the agricultural management committees under the Commission. Together with the agricultural advisory committees, these have sometimes been characterised negatively as the 'agricultural circuit', or as "reinforcing the closed shop that ha[d] been largely achieved by the ministers and their civil servants in all CAP matters". ${ }^{54}$ It has thus been argued that this relatively closed, sectoral policy loop meant that new ideas had difficulties penetrating CAP policy-making, making reform difficult, even once it became apparent towards the end of the 1960s that the original policy principles of the CAP had a series of unintended consequences. Yet it is also important to realise that the CAP actually integrated some of the most conservative and entrenched branches of governments, injecting them with high doses of European administration and regulation in their day-to-day practices. In the light of this, it seems plausible to suggest that had these nationally situated actors not been enticed to accept the CAP, they would have been in a position to make the running of the CAP very complicated. Instead, during the 1960s the administrative fusion of agricultural politics led to a much larger political space that went beyond the classical two-level games that the Community of the 1960s has still largely been conceptualised as. The emergence of the committee structures founded between 1960 and 1962 was crucial in this regard.

A second major process that the committees set in motion was that of furthering the socialisation of the actors involved. Institutions, thus also committees, constitute social environments, and social scientists have pointed out that participation can lead to the socialisation of actors. It is thus argued that institutions can affect the most basic preferences of the individual actors. The extent to which socialisation happens, what beliefs people may get socialised into, and what it means for the outcome of the process can be extremely difficult to gage even for contemporary research. ${ }^{55}$ There

51. A. SWINBANK, The British Interest and the Green Pound, Reading: Center for Agricultural Strategy, University of Reading, Reading, 1978, p.67.

52. S. HIX, The Political System ..., op.cit.

53. W. WESSELS, An Ever Closer Fusion? ..., op.cit.

54. E. NEVILLE-ROLFE, The Politics of Agriculture in the European Community, Institute for Policy Studies, London, 1984, p.208.

55. J.T. CHECKEL, Why Comply? Social Learning and European Identity Change, in: International Organization, 3(2001), pp.553-588. 
are therefore good reasons to be careful about making generalisations about socialisation for historical periods. Yet, rather than rejecting it, we believe that the key theoretical insights about socialisation are worth taking into consideration, to the extent that this is possible. Sources are available from oral histories, (auto)-biographies, interviews, and personal archives. There is no reason to believe that a 'national' official is not affected by his or her institutional environment. Thus, basic contexts such as when leading national officials began to meet on a frequent basis both with their colleagues from around the Community and with Commission officials in the various committees, they often realised that they had more in common than with their domestic colleagues in other branches of national administration. We know that this was often the case in the agricultural sector. ${ }^{56}$ It has also been shown that as the permanent representatives began to spend more time with each other than they did together with their nationally located colleagues, their beliefs began to align. This reduced many potential tensions and made compromises easier. ${ }^{57}$ In short, it is important to keep an open mind with regard to the possible forms of socialisation that may have taken place. Even though we cannot prove exactly how or to what degree this occurred, we can at least try to understand the mechanisms that followed from the 'fusion' that resulted when thousands of nationally paid officials began participating in the committees.

All of this has important consequences for notions of control by the member states. The political process of the EC became much more blurred than the formal description of institutional competences in the founding treaties, or than theoretical notions of member state control, would lead us to believe. Certainly the member states were still there, but rather than being unitary actors in any way, they became increasingly represented by a myriad of national officials who may not always have acted 'nationally'. The ministers in the Council often did not represent governments as unitary actors, as even the work in the Council was functionally divided. This was a development towards a European political system that began in earnest within a few years of the EEC treaty's entering into force, and which was already firmly in place at the time when scholars studying more contemporary political developments began to identify this. We expect that further historical scholarship will confirm this.

56. C. DAUGBJERG, F. JUST, Internationaliseringen af landbrugsforvaltningen og nationale magtkonstallationer, in: M. MARCUSSEN, K. RONIT (eds.), Internationaliseringen af den offentlige forvaltning i Danmark - Forandring og kontinuitet, Århus Universitetsforlag, Århus, 2003, pp.128-155.

57. J. BATORA, Does the European Union Transform the Institution of Diplomacy?, in: Journal of European Public Policy, 12(2005), pp.44-66. 


\section{Conclusion}

In this article we argued in favour of a new research agenda in the historiography of European integration, a call also made by Wolfram Kaiser and Brigitte Leucht in this volume. We surveyed the emergence and early development of the Community committee structures that represented a cornerstone in the emergence of a European political system. The new committee structures played a central role in the fusion of national administrations with the European ones in the areas of common policies. It seems unlikely that it would otherwise have been feasible to formulate, adopt, implement and eventually run such a comprehensive and central public policy as for example the CAP. In combination with the establishment of a strong supranational legal system, as was promoted by the European Court of Justice with the Van Gend en Loos (1963) and Costa v. Enel (1964) rulings ${ }^{58}$ this new administrative fusion was also quite simply a precondition for the success and stability of the EC in the longer run.

Analysing the committee structures over time, we demonstrated several significant features and consequences. Firstly, there was the very deliberate separation of the functioning of the Council(s) that emerged, which also divided the work between the COREPER and the SCA as the primary preparatory committees. If member state governments wished to assure a unified voice here, they would have to have a very well-developed coordination of their EC policy representation. A few member states certainly did, but it does not merit the conclusion of member state control. Secondly, the committee structures created a very broad interface between the EC and national administrations and brought in many actors who would not normally have been involved in foreign policy. The consequence of this was a very dispersed flow of information and communication, and the opening of multiple entry points for influencing the EC policy process. Thirdly, systematic institutional overlaps between the Commission, the Council and representatives of national administrations in the preparation and passing of legislation led to a blurring of the decision-making process. It simply became more difficult to identify exactly whose decision it was. Finally, potential processes of socialisation are likely to have caused a degree of convergence between the outlook of national and European officials, especially in the areas of common policies and cooperation, and thus reduced potential conflicts in the European political system.

Taken together, these features and consequences of the committee structures undermine the notion of member states acting in a unitary manner in relation to the EC policy processes. They also fundamentally question the notion of member state 'control', as well as that of 'national interests', that are so often applied in the literature. We can certainly find numerous individual examples of member states censoring the Commission or providing tight negotiation mandates for their

58. M. RASMUSSEN, From Costa v. ENEL to the Treaties of Rome - A brief history of a legal revolution, in: M. P. MADURO, L. AZOULAI (eds.), The Future of European Law - Revisiting the Classics in the 50 $0^{\text {th }}$ Anniversary of the Rome Treaty, Hart Publishing, Oxford, 2008, (forthcoming). 
representatives, which can be matched with final policy outcomes. Nonetheless, we argue that such examples should be seen in the context of the overall myriad of political and 'expert' actors who had access and opportunity to mould the policy process through participation in the committee structures. In this manner, historians of European integration need to try and grasp the larger historical picture.

While we admittedly drew extensively on the experiences of agricultural policy making, these tendencies were of a general nature and applied to various degrees to different kinds of European policy making. ${ }^{59}$ This has most recently been confirmed in Laurent Warlouzet's analysis of French European policy towards the industrial Common Market during the formative period of the EC from 1958 to 1969 that reaches similar conclusions. ${ }^{60}$ Indeed, it is argued that not only did the committee system undermine the coherence of national positions, resulting in gains in influence of the Commission; French economic civil servants were also gradually europeanised. Considering how Gaullist France is generally portrayed in the historical literature as the epitome of a unitary state actor, pursuing national interests relentlessly, we find our argument here confirmed by the case least likely.

To represent the history of the European Union and the member states in terms of a sui generis model or zero-sum logic is about as ahistorical as claiming that social organisations do not change or adapt. Historians can certainly still write the histories of the member states, but they need to abandon the rather unfruitful assumptions of unitary member state behaviour vis-à-vis the Community, and thus the notion of member state 'control'. National and supranational histories alike need a much more subtle conceptualisation of the multifaceted nature of the social processes at stake in the face of the creation of the European Communities. We have here suggested an opening by applying concepts used in the new institutionalism literature, which has in fact also been used by historians of modern states in earlier periods. These challenges must be met if the historiography of the European integration process is to become more relevant to other disciplines.

59. On the changing nature of foreign offices, the Council and diplomatic practices: J. BATORA, Does the European Union ..., op.cit.; also, H. WALLACE, F. HAYES-RENSHAW, The Council of Ministers, Palgrave Macmillan, London, 2006, $2^{\text {nd }}$ ed.; D. SPENCE, B. HOCKING (eds.), Foreign Ministries and the European Union. Integrating Diplomats, Palgrave Macmillan, London, 2005. On the so-called Europeanisation of national administrations, e.g.: J.P. OLSEN, The Many Faces of Europeanization, in: Journal of Common Market Studies, 5(2002), pp.921-952; C. KNILL, The Europeanisation of National Administrations. Patterns of Institutional Change and Persistence, Cambridge University Press, Cambridge, 2001.

60. See the dissertation defended in December 2007: L. WARLOUZET, Quelle Europe économique pour la France? La France et le Marché commun industriel, 1956-1969, Dissertation, Université Paris IV-Sorbonne, Paris, 2007. 


\section{Aktuelle Neuerscheinungen}

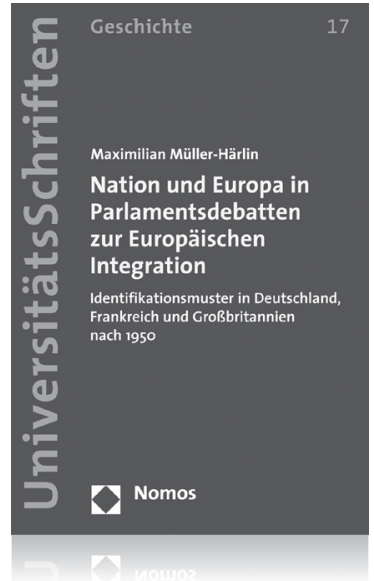

\section{Nation und Europa in Parlaments- debatten zur Europäischen Integration}

Identifikationsmuster in Deutschland, Frankreich und Großbritannien nach 1950 Von Dr. Maximilian Müller-Härlin 2008, 626 S., brosch., 98,-€, ISBN 978-3-8329-3291-6

(Nomos Universitätsschriften Geschichte, Bd. 17)

Erscheint Juni 2008

Wie viel Nation und wie viel Europa „stecken“ in der Europäischen Integration?

Die vieldiskutierte Frage wird hier zum ersten Mal in einem anspruchsvollen Vergleich der großen Parlamentsdebatten zum SchumanPlan und zu den Maastrichter Verträgen beantwortet. Der Autor analysiert semantisch genau Konsens und Konflikt, Selbst- und Fremdbilder und den Wandel der Werte.

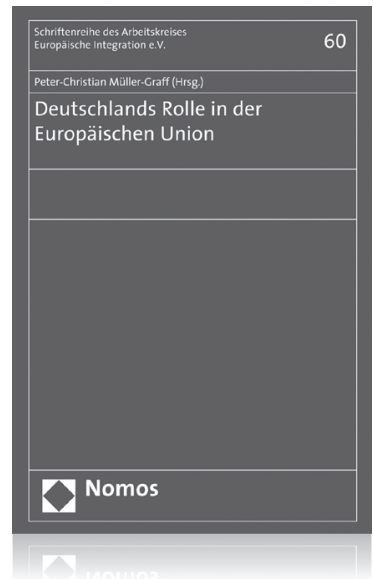

\section{Deutschlands Rolle in der Europäischen Union}

Herausgegeben von Prof.

Dr. Dr. h.c. Peter-Christian Müller-Graff

2008, 352 S., brosch., 64,- $€$,

ISBN 978-3-8329-3333-3

(Schriftenreihe des Arbeitskreises

Europäische Integration e.V., Bd. 60)

Erscheint Juni 2008

Deutschlands Rolle in der EU ist im Vorfeld und Umkreis der Deutschen Ratspräsidentschaft 2007 vielfältig thematisiert worden. Inwieweit Deutschland dieser Verantwortung gerecht wird und werden kann, war Gegenstand des interdisziplinären Jahreskolloquiums des AEI. Der vorliegende Band enthält die zehn Tagungsbeiträge, die um drei weitere Beiträge ergänzt wurden. 


\section{Relancer la CEE avant la Chaise vide: Néo-fonctionnalistes vs. fédéralistes au sein de la Commission européenne (1964-1965)}

\section{Laurent WARLOUZET}

Les études historiques et de science politique sur l'intégration européenne cherchent de plus en plus à embrasser la complexité et les contradictions du système institutionnel communautaire, et tendent à remettre en cause certains schémas simplificateurs anciens. ${ }^{1}$ Ainsi, l'unicité de l'acteur étatique a été remise en cause par de nombreux politistes, y compris ceux qui mettent les États-membres au centre du processus de décision comme les intergouvernementalistes libéraux. ${ }^{2}$ De même certains historiens ont souligné les oppositions existantes au sein d'un même gouvernement ou entre deux administrations. ${ }^{3}$ Pourtant, dans le cas d'un acteur essentiel, la Commission européenne, les divisions doctrinales existant en son sein ont été rarement étudiées. ${ }^{4}$ Les commissaires européens sont en général considérés soit comme des européistes militants unis par un projet commun, soit comme de simple relais de leurs gouvernement national.

Grâce au recours aux théories de la science politique, il est pourtant possible de différencier plusieurs lignes de pensée au sein de la Commission européenne. La science politique permet en effet de dépasser la simple accumulation de faits de l'histoire-récit pour interpréter une série d'attitudes en les associant à une stratégie institutionnelle de promotion de l'intégration européenne. Tous les partisans de l'intégration européenne en poste au sein de la Commission européenne ne défendent pas le même programme pour la CEE. Le recours aux théories des sciences politiques permet en particulier de mieux comprendre le déclenchement de la crise de la Chaise vide, qui a déjà été étudié abondamment mais principalement du point de vue des États. ${ }^{5}$ Or, entre la fin 1964 et le début de 1965, juste avant la crise de la Chaise vide, l'approche néo-fonctionnaliste du

1. Cet article s'appuie sur des recherches menées dans le cadre d'un doctorat soutenu en 2007 et dirigé par le professeur Éric Bussière (Paris IV-Sorbonne) sur: Quelle Europe économique pour la France (1956-1969)?

L'auteur remercie les professeurs Jan van der Harst et Wolfram Kaiser pour leurs remarques sur des versions antérieures.

2. A. MORAVCSIK, The Choice for Europe. Social Purpose and State Power from Messina to Maastricht, UCL Press, Londres, 1999, p.22.

3. Voir par exemple l'étude de cas de la seconde candidature britannique dirigée par O. DADDOW (éd.), Harold Wilson and European Integration. Britain's Second Application to join the EEC, Frank Cass, Londres, 2003 ou le colloque sur les cultures européennes des différentes administrations (L. BADEL, S. JEANNESSON, P. LUDLOW (dir.), Les administrations nationales et la construction européenne. Une approche historique (1919-1975), PIE-Peter Lang, Bruxelles, 2005).

4. On trouve quelques allusions à ces divisions dans M. DUMOULIN (dir.), Histoire de la Commission européenne, 1958-1974, Histoire et Mémoires d'une Institution, Office des Publications officielles des Communautés Européennes, Luxembourg, 2007. 